\title{
Identification of Peanut Interspecific Pre-breeding Lines resistance to Peanut Bud Necrosis Disease (PBND): Field Screening, Morphological and Biochemical Parameters
}

\author{
M.D. Jasani ${ }^{*}$, A.K. Maurya ${ }^{2}$, P. Dash², J.H. Kamdar², G. Sunkad ${ }^{3}$, \\ M.K. Mahatma ${ }^{2}$ and S.K. Bera ${ }^{2}$ \\ ${ }^{1}$ Department of Biosciences, Saurashtra University, Rajkot 360 001, Gujarat, India \\ ${ }^{2}$ ICAR-Directorate of Groundnut Research, Junagadh 362 001, Gujarat, India \\ ${ }^{3}$ Department of Plant Pathology, University of Agricultural Sciences, \\ Raichur 584104, Karnataka, India \\ *Corresponding author
}

\section{A B S T R A C T}

Keywords

Peanut, Peanut bud necrosis disease, Morphological and biochemical characters

Article Info

Accepted:

17 January 2018

Available Online:

10 February 2018
Peanut bud necrosis disease is one of the major viral diseases in peanut. Interspecific peanut pre-breedinglines along with susceptible checks (KRG-1 and TMV2) were tested under field conditions at hot spot location over two seasons. Out of 34 lines, 16 lines were found resistant, while 16 were moderately resistant. Significant negative association was observed between PBND incidence and phenol content, number of trichomes on leaf, petioles and stem. While significant positive association was observed between PBND incidence and total soluble sugar, free amino acid and leaf thickness. Higher phenol content, number of trichomes on leaf, stem and petioles and dark green leaf colour might have contributed a major role in imparting resistance to PBND in these peanut lines. Prebreeding lines NRCGCS Nos. 79, 86, 159 and 301, belong to virginia habit group, were found with less disease score, higher amount of phenol, more number of trichomes on leaf, stem and petioles and dark green leaf color compared to susceptible checks. These interspecific pre-breeding lines would be fresh sources for resistance to PBND for peanut breeding programme.

\section{Introduction}

Peanut (Arachis hypogaea L.), an important oilseed and food crop is cultivated in $\sim 25.70$ $\mathrm{m}$ ha, spreading across more than 100 countries, with a production of $\sim 42.32 \mathrm{~m}$ tons of in-shell peanuts during 2014 (FAO, 2015). China, India, USA and Nigeria are leading peanut producing countries in the world.
Peanut seeds provide balanced nutrition to human diets in the form of edible oil $(\sim 50 \%)$, proteins $(\sim 25 \%)$ and carbohydrates $(\sim 18 \%)$ (Darvhankar et al., 2016). It enhances soil heath through nitrogen fixation as a legume crop (Bertioli et al., 2016). Insect pests are one of the major factors contributing to yield loss. More than 50 species of insects have been recorded on peanut, of which sucking pests like thrips are causing severe losses in 
recent past (Naik and Somashekhar, 2015). Peanut bud necrosis disease (PBND) caused by peanut bud necrosis virus (PBNV) vectored by Thripspalmi Karny (Vijayalakshmi et al., 1995) has emerged as a serious yield constraint in South and Southeast Asia. Up to $80 \%$ yield losses were reported due to PBND in India (Singh and Srivastava, 1995). Besides peanut, it also infects chili, potato, tomato, tobacco, mung bean and urdbean (Jasani and Kamdar, 2015; Readdy et al., 1995). The yield loss due to PBND in peanut mainly depends on the time of infection. If the infection occurs on young plants (before 60 days after sowing) pod yield loss will be $100 \%$ (Gopal and Upadhyaya, 1988). If infection occurs after the plants start to produce pods, losses are minimal. The symptoms caused by PBNV are highly variable, but they are not genotype specific (Reddy, 1988). Thrips damage on peanut crop can be curtailed by breeding varieties which can genetically or physically resist the feeding by thrips (Krishnaiah et al., 2012). Progress has been made in breeding peanut for resistance to PBND and several high-yielding peanut lines resistant to PBND have been generated over the years (Naik and Somashekha, 2015; Bera et al., 2014, 2010a, 2010b; Kamdar et al., 2014; Kandakoor et al., 2014; Reddy et al., 1995) but complete host plant resistance to PBNV is scarce. Sometimes low disease incidence in certain lines could be because of vector nonpreference (Buiel, 1993).

Resistance in plants is governed by genetical, morphological and biochemical parameters. Pensuk et al., (2004) reported that the type of gene action governing resistance to PBND was non additive and controlled by multiple genes. Linch and Stalker, (1997) reported antibiosis as a basis of resistance to thrips in wild Arachis species and interspecific hybrids. Every plant has an inbuilt mechanism to resist the attack of the pest constituting various morpho-features and biochemicals
(Naik and Somashekhar, 2015). In addition, plants with trichomes also have characteristics of insect and disease resistance (Hong-qin and Jian-ping, 2010). Trichomes may offer a potential insect resistance mechanism for glabrous crops and/or genotypes (Peter et al., 1995). Some of peanut genotypes had the characteristic features of wavy margin leaves and down ward folding of the leaves, which contribute to the restriction of thrips movement (Rao et al., 2015). It is also possible that the host plants may produce certain chemicals after the attack of insect pests and diseases causing pathogens as a defense mechanism with varied degree of symptoms production due to attack (Naik and Somashekhar, 2015).

The biochemical parameters viz., total soluble sugar, phenols and free amino acids are some of the contributing factors may vary with different genotypes/varieties. Sugar is an important biochemical content in the plant system which plays a pivotal role in governing lot of physiological activities. Rohini et al., (2011) reported that the presence of high quantity of biochemical components like tannins, phenols conferred resistance against thrips. Naik (2005) reported that thrips population and phenol content were strongly associated showing significant and negative relationship.

In peanut crop wide phenotypic (morphological and anatomical differences) and/or genotypic (genetically) variability has been observed (Kandakoor et al., 2014). Considering these facts, investigation was taken up with an aim to identify resistant genotype against PBND. In present study, selected peanut pre-breeding lines were screened for resistance to PBND. Further role of various morphological and biochemical traits were studied to find the association of these traits with resistance. 


\section{Materials and Methods}

\section{Plant materials}

ICAR-Directorate of Groundnut Research (ICAR-DGR), Junagadh, India has developed a large number of interspecific pre-breeding lines over a period of time to introgress desirable genes from wild Arachis species to cultivated peanut. Earlier, a total of 435 interspecific pre-breeding lines were screened during kharif 2010 and rabi 2011 (Kamdar et al., 2014) and 42 lines were reported highly resistant. Out of 42 lines34 interspecific prebreeding lines (Table 2) were selected (based on availability of seeds) for further screening and biochemical and morphological analysis.

\section{Screening of PBND resistance}

34 interspecific pre-breeding lines along with two susceptible checks viz. KRG-1 and TMV2 were screened under naturalfield conditions in the farm of University of Agricultural Sciences (UAS), Raichur, Karnataka, a hot spot for PBND during Kharif 2011 and Rabi 2016.

Raichur is situated between $16^{\circ} 15^{\prime} \mathrm{N}$ latitude and $77^{\circ} 20^{\prime} \mathrm{E}$ longitude at an elevation of 389 $\mathrm{m}$ above mean sea level with an average rainfall of $621.33 \mathrm{~mm}$. Lines were planted in Randomised Block Design (RBD) with three replications. The crop was sown as per the recommended package of practices except for the plant protection measures against PBND.

Each interspecific pre-breeding line was sown in 2 rows of $5 \mathrm{~m}$ length and at every 4th row, susceptible checks were planted with a spacing of $45 \mathrm{~cm}$ between rows and $10 \mathrm{~cm}$ between plants. Crop grown during rabi season was irrigated at regular interval whereas lifesaving irrigation was provided to kharif season crop to maintain healthy growth of the crop. Initial plant count was recorded in all lines at 20 days after sowing while the number of healthy and diseased plants were recorded one week before harvest of the crop and expressed in terms of percent disease incidence. The percent PBND incidence was calculated by using the formula "Percent disease $(\%)=($ Number of PBND infected plants/ Total number of plants) X 100" and was pooled over seasons. Based on pooled disease incidence, lines were grouped into different categories following standard (0-5) disease rating scale (Table 1) (Sunkad et al., 2012). These interspecific pre-breeding lines were further studied for morphological and biochemical analysis.

\section{Morphological observations}

Leaves of 30 days old plants were collected for morphological observations viz., leaf trichomes, petioles trichomes, stem trichomes, leaf thickness, leaf colour. Leaf trichomes, petioles trichomes and stem trichomes were counted from a one fully expanded leaf. Observations were recorded in three replication.

The leaves were examined under a phase contrast microscope at a magnification of 100X (Laborlux S, Leitz, Germany). Number of trichomes on leaf, petiole and stem were counted randomly at five places and the average trichome density was expressed as the number of trichomes per square millimeter.

For measuring leaf thickness, thin transverse sections were taken and observed under calibrated phase contrast microscope (Laborlux S, Leitz, Germany) at 45X magnification. Leaf thickness was measured using a pre-calibrated ocular micrometer and the length was expressed in millimeters $(\mathrm{mm})$.Visual observation was made on the leaf colour and categorized as light green and dark green. 


\section{Biochemical observations}

For biochemical analysis, leaves $(100 \mathrm{mg})$ were extracted with $5 \mathrm{ml}$ of $80 \%$ ethanol and centrifuged at $3000 \mathrm{rpm}$ for 10 minutes. Extraction was repeated 4 times with $80 \%$ ethanol and supernatants were collected into volumetric flasks. Final volume of the clear extract was made up to $25 \mathrm{ml}$ with $80 \%$ ethanol from which aliquots were taken for the estimation of total soluble sugars (TSS), Phenol content and free amino acid. TSS was estimated by anthrone method (Franscist et al., 1971). Total phenolics were determined using Folin and Ciocalteu reagent and 20\% $\mathrm{Na}_{2} \mathrm{CO}_{3}$ as described in Malik and Singh., 1980. Total free amino acid in the free pool of plant cells were determined by using ninhydrin method (Lee and Takahanshi., 1966). The absorbance of each observation in a sample was measured by using spectrophotometer (2202, Systronics).

\section{Statistical calculation}

The replication wise values of each interspecific pre-breeding lines with two susceptible checks were used for statistical analysis. The standard error of mean (S.Em.), critical difference (C.D.), coefficient of variation (C.V. \%) were analyzed using formula describe in Darvhankar (2017). To find out the association of various morphological, biochemical observation and PBND incidence, simple correlation coefficients were calculated using analysis toolkit menu in Microsoft Excel software.

\section{Results and Discussion}

\section{Field screening}

Field screening of 34 interspecific prebreeding lines with susceptible checks (KRG1 and TMV2) was done at UAS, raichur, Karnataka during kharif 2011 and rabi 2016. Raichur, Karnataka, India reported as natural hot spot for PBND (Basu.,1995).Based on pooled disease incidence over four(kharif 2010, rabi 2011, kharif 2011 and rabi 2016) seasons, no interspecific pre-breeding line was found highly resistant. Among 34 interspecific pre-breeding lines, 16 lines(NRCGCS nos. 79, 81, 85, 86, 159, 246, $267,271,275,282,285,286,300,301,319$, 327) were found resistant, while 16 lines (NRCGCS nos. 36, 46, 51, 55, 57, 58, 82, $102,103,153,161,177,262,269,417,421)$ were moderately resistant and 2 lines (NRCGCS nos. 2,8) were found moderately susceptible (Table 3). The mean PBND incidence in resistant lines ranged from 1.1\% (NRCGCS-267) to 5\% (NRCGCS-86) and moderately resistant group, it ranged from 5.2\% (NRCGCS-82) to $9.7 \%$ (NRCGCS-46). In moderately susceptible lines, minimum disease incidence of $10.6 \%$ was recorded in NRCGCS-2 and maximum of $10.8 \%$ in NRCGCS-8. In susceptible checks, the disease incidence ranged from 46.6\% (KRG1) to $55.15 \%$ (TMV2). More than $55 \%$ disease incidence was observed in the susceptible check (TMV2) confirming high disease pressure under normal field conditions at experimental location (Table 3 ).

Table.1 PBND disease incidence scale

\begin{tabular}{|l|l|l|}
\hline Scale & Per cent incidence & Disease reaction \\
\hline $\mathbf{0}$ & 0 to $1 \%$ infection & Highly Resistant (HR) \\
\hline $\mathbf{1}$ & 1.1 to $5 \%$ infection & Resistant (R) \\
\hline $\mathbf{2}$ & 5.1 to $10 \%$ & Moderately Resistant (MR) \\
\hline $\mathbf{3}$ & 10.1 to $25 \%$ & Moderately susceptible (MS) \\
\hline $\mathbf{4}$ & 25.1 to $50 \%$ & Susceptible (S) \\
\hline $\mathbf{5}$ & $50.1 \%$ and above & Highly susceptible (HS) \\
\hline
\end{tabular}

Source: -Sunkad et al., 2012 
Table. 2 List of selected interspecific pre-breeding lines of peanut used in the study

\begin{tabular}{|c|c|c|c|}
\hline Sr. No. & Pl. No. & Pedigree & Habit Group \\
\hline 1 & NRCGCS-2 & CT7-1 $\times$ SBXI & Virginia bunch \\
\hline 2 & NRCGCS-8 & CT7-1 × SBXI & Virginia bunch \\
\hline 3 & NRCGCS-36 & CT7-1 × SBXI & Spanish bunch \\
\hline 4 & NRCGCS-46 & CT7-1 × SBXI & Virginia bunch \\
\hline 5 & NRCGCS-51 & CT7-1 $\times(\mathrm{SBXI} \times A$. pusilla $)$ & Spanish bunch \\
\hline 6 & NRCGCS-55 & CT7-1 $\times(\mathrm{SBXI} \times A$. pusilla $)$ & Virginia bunch \\
\hline 7 & NRCGCS-57 & $\mathrm{CT} 7-1 \times \mathrm{SBXI}$ & Virginia bunch \\
\hline 8 & NRCGCS-58 & CT7-1 $\times$ SBXI & Virginia bunch \\
\hline 9 & NRCGCS-79 & CT7-1 $\times$ SBXI & Virginia bunch \\
\hline 10 & NRCGCS-81 & CT7-1 $\times$ SBXI & Virginia bunch \\
\hline 11 & NRCGCS-82 & CT7-1 $\times($ SBXI $\times A$. diogoi $)$ & Virginia bunch \\
\hline 12 & NRCGCS-85 & CT7-1 $\times(\mathrm{SBXI} \times A$. diogoi $)$ & Spanish bunch \\
\hline 13 & NRCGCS-86 & CT7-1 $\times(\mathrm{SBXI} \times A$. correntina $)$ & Virginia bunch \\
\hline 14 & NRCGCS-102 & CT7-1 × SBXI & Virginia bunch \\
\hline 15 & NRCGCS-103 & CT7-1 × SBXI & Virginia bunch \\
\hline 16 & NRCGCS-153 & GG $11 \times$ A. chacoence & Virginia bunch \\
\hline 17 & NRCGCS-159 & GAUG $10 \times$ CGC 4018 & Virginia bunch \\
\hline 18 & NRCGCS-161 & GG $2 \times A$. manfridi & Virginia bunch \\
\hline 19 & NRCGCS-177 & J $11 \times$ A. duranensis & Virginia bunch \\
\hline 20 & NRCGCS-246 & GG $2 \times A$. cardenasii & Virginia bunch \\
\hline 21 & NRCGCS-262 & $(\mathrm{DR} \times \mathrm{PV}) \times$ A.duranensis & Spanish bunch \\
\hline 22 & NRCGCS-267 & $\mathrm{PT} \times \mathrm{DR}$ & Spanish bunch \\
\hline 23 & NRCGCS-269 & $\mathrm{DR} \times \mathrm{PV}$ & Virginia bunch \\
\hline 24 & NRCGCS-271 & $\mathrm{DR} \times \mathrm{PV}$ & Virginia bunch \\
\hline 25 & NRCGCS-275 & $\mathrm{DR} \times \mathrm{PV}$ & Spanish bunch \\
\hline 26 & NRCGCS-282 & $\mathrm{DR} \times \mathrm{PV}$ & Virginia bunch \\
\hline 27 & NRCGCS-285 & $\mathrm{PT} \times \mathrm{DR}$ & Virginia bunch \\
\hline 28 & NRCGCS-286 & VRI-4 $\times$ A. cardenansii & Virginia bunch \\
\hline 29 & NRCGCS-300 & $\mathrm{J} 11 \times A$. duranensis & Virginia bunch \\
\hline 30 & NRCGCS-301 & J $11 \times$ A. kretschmeri & Virginia bunch \\
\hline 31 & NRCGCS-319 & $\mathrm{J} 11 \times A$. duranensis & Virginia bunch \\
\hline 32 & NRCGCS-327 & $\mathrm{J} 11 \times A$. duranensis & Virginia bunch \\
\hline 33 & NRCGCS-417 & GG $-2 \times(\mathrm{J} 11 \times A$. monticola $)$ & Virginia bunch \\
\hline 34 & NRCGCS-421 & GG $-2 \times(\mathrm{J} 11 \times$ A. batizocoi $)$ & Virginia bunch \\
\hline 35 & KRG-1 & Selection from Argentina variety & Spanish bunch \\
\hline 36 & TMV2 & Selection from Gudhiyatham bunch & Spanish bunch \\
\hline
\end{tabular}

Source: -Bera et al., 2016; Rathnakumar et al., 2013 
Table.3 PBND disease incidence over four seasons and disease reaction of 34 interspecific prebreeding lines of peanut with KRG-1 and TMV2

\begin{tabular}{|c|c|c|c|c|c|c|c|}
\hline \multirow[t]{2}{*}{ Sr. No. } & \multirow[t]{2}{*}{ Plant No. } & \multicolumn{5}{|c|}{ PBND Incidence (\%) } & \multirow[b]{2}{*}{ Reaction } \\
\hline & & $\begin{array}{l}\text { Kharif } \\
\text { 2010* }\end{array}$ & $\begin{array}{c}\text { Rabi } \\
2011^{*}\end{array}$ & $\begin{array}{c}\text { Kharif } \\
2011\end{array}$ & $\begin{array}{l}\text { Rabi } \\
2016\end{array}$ & Mean & \\
\hline 1 & NRCGCS-2 & 0.0 & 1.8 & 25.0 & 15.6 & 10.6 & MS \\
\hline 2 & NRCGCS-8 & 0.0 & 0.0 & 30.0 & 13.3 & 10.8 & MS \\
\hline 3 & NRCGCS-36 & 0.0 & 1.6 & 8.0 & 13.3 & 5.7 & MR \\
\hline 4 & NRCGCS-46 & 0.0 & 0.0 & 13.0 & 25.6 & 9.7 & MR \\
\hline 5 & NRCGCS-51 & 0.0 & 0.0 & 12.5 & 13.3 & 6.5 & MR \\
\hline 6 & NRCGCS-55 & 0.0 & 0.0 & 15.4 & 8.9 & 6.1 & MR \\
\hline 7 & NRCGCS-57 & 0.0 & 2.0 & 16.7 & 11.1 & 7.4 & MR \\
\hline 8 & NRCGCS-58 & 0.0 & 1.1 & 16.7 & 13.3 & 7.8 & MR \\
\hline 9 & NRCGCS-79 & 0.0 & 0.0 & 8.7 & 6.7 & 3.8 & $\mathrm{R}$ \\
\hline 10 & NRCGCS-81 & 0.0 & 1.6 & 10.5 & 6.7 & 4.7 & $\mathrm{R}$ \\
\hline 11 & NRCGCS-82 & 0.0 & 1.8 & 10.0 & 8.9 & 5.2 & MR \\
\hline 12 & NRCGCS-85 & 0.0 & 0.0 & 11.1 & 6.7 & 4.4 & $\mathrm{R}$ \\
\hline 13 & NRCGCS-86 & 0.0 & 0.0 & 13.3 & 6.7 & 5.0 & $\mathrm{R}$ \\
\hline 14 & NRCGCS-102 & 0.0 & 1.4 & 15.4 & 13.3 & 7.5 & MR \\
\hline 15 & NRCGCS-103 & 0.0 & 0.0 & 13.3 & 15.6 & 7.2 & MR \\
\hline 16 & NRCGCS-153 & 0.0 & 1.6 & 9.1 & 13.3 & 6.0 & MR \\
\hline 17 & NRCGCS-159 & 0.0 & 0.0 & 9.5 & 6.7 & 4.0 & $\mathrm{R}$ \\
\hline 18 & NRCGCS-161 & 0.0 & 0.0 & 9.1 & 13.3 & 5.6 & MR \\
\hline 19 & NRCGCS-177 & 0.0 & 13.6 & 15.8 & 6.7 & 9.0 & MR \\
\hline 20 & NRCGCS-246 & 0.0 & 0.0 & 0.0 & 6.7 & 1.7 & $\mathrm{R}$ \\
\hline 21 & NRCGCS-262 & 0.0 & 1.8 & 23.5 & 4.4 & 7.4 & MR \\
\hline 22 & NRCGCS-267 & 0.0 & 0.0 & 0.0 & 4.4 & 1.1 & $\mathrm{R}$ \\
\hline 23 & NRCGCS-269 & 0.0 & 0.0 & 12.0 & 8.9 & 5.2 & MR \\
\hline 24 & NRCGCS-271 & 0.0 & 0.0 & 12.5 & 6.7 & 4.8 & $\mathrm{R}$ \\
\hline 25 & NRCGCS-275 & 0.0 & 0.0 & 0.0 & 8.9 & 2.2 & $\mathrm{R}$ \\
\hline 26 & NRCGCS-282 & 0.0 & 0.0 & 13.0 & 6.7 & 4.9 & $\mathrm{R}$ \\
\hline 27 & NRCGCS-285 & 0.0 & 0.0 & 6.7 & 4.4 & 2.8 & $\mathrm{R}$ \\
\hline 28 & NRCGCS-286 & 0.0 & 0.0 & 0.0 & 11.1 & 2.8 & $\mathrm{R}$ \\
\hline 29 & NRCGCS-300 & 0.0 & 1.8 & 0.0 & 11.1 & 3.2 & $\mathrm{R}$ \\
\hline 30 & NRCGCS-301 & 0.0 & 0.0 & 0.0 & 6.7 & 1.7 & $\mathrm{R}$ \\
\hline 31 & NRCGCS-319 & 0.0 & 0.0 & 0.0 & 6.7 & 1.7 & $\mathrm{R}$ \\
\hline 32 & NRCGCS-327 & 0.0 & 0.0 & 0.0 & 8.9 & 2.2 & $\mathrm{R}$ \\
\hline 33 & NRCGCS-417 & 0.0 & 0.0 & 18.8 & 13.3 & 8.0 & MR \\
\hline 34 & NRCGCS-421 & 0.0 & 0.0 & 23.1 & 13.3 & 9.1 & MR \\
\hline 35 & KRG-1 & 61.0 & 60.0 & 40.0 & 25.6 & 46.6 & $\mathrm{~S}$ \\
\hline 36 & TMV2 & 67.0 & 64.0 & 54.0 & 35.6 & 55.2 & S \\
\hline
\end{tabular}

* Source: -Bera et al., 2016. 
Table.4 Morphological and biochemical parameters of 34 interspecific pre-breeding lines of peanut with KRG-1 and TMV2

\begin{tabular}{|c|c|c|c|c|c|c|c|c|c|}
\hline & & & LT & PT & ST & LTHs & TSS & Phenol & FAA \\
\hline Sr. No. & Plant No. & $\mathbf{L C}$ & $\left(\mathrm{mm}^{2}\right)$ & $\left(\mathrm{mm}^{2}\right)$ & $\left(\mathrm{mm}^{2}\right)$ & $(\mathbf{m m})$ & $(\mathrm{mg} / \mathrm{g})$ & $(\mathrm{mg} / \mathrm{g})$ & $(\mathrm{mg} / \mathrm{g})$ \\
\hline 1 & NRCGCS-2 & DG & 3.89 & 3.17 & 2.78 & 0.32 & 7.44 & 0.39 & 5.05 \\
\hline 2 & NRCGCS-8 & LG & 3.44 & 3.29 & 3.24 & 0.33 & 7.35 & 0.42 & 4.45 \\
\hline 3 & NRCGCS-36 & DG & 7.34 & 5.95 & 2.91 & 0.23 & 5.05 & 0.51 & 3.74 \\
\hline 4 & NRCGCS-46 & DG & 4.56 & 4.30 & 4.18 & 0.25 & 5.45 & 0.45 & 3.61 \\
\hline 5 & NRCGCS-51 & LG & 6.33 & 5.19 & 3.16 & 0.23 & 5.91 & 0.44 & 4.05 \\
\hline 6 & NRCGCS-55 & DG & 6.08 & 6.58 & 3.54 & 0.23 & 5.35 & 0.56 & 3.57 \\
\hline 7 & NRCGCS-57 & DG & 7.47 & 4.56 & 2.66 & 0.25 & 6.18 & 0.43 & 4.59 \\
\hline 8 & NRCGCS-58 & LG & 3.67 & 4.43 & 3.20 & 0.31 & 6.02 & 0.48 & 3.58 \\
\hline 9 & NRCGCS-79 & DG & 7.72 & 6.84 & 3.80 & 0.22 & 4.11 & 0.95 & 3.67 \\
\hline 10 & NRCGCS-81 & DG & 5.44 & 3.80 & 2.53 & 0.29 & 6.21 & 0.91 & 2.58 \\
\hline 11 & NRCGCS-82 & DG & 5.19 & 4.94 & 3.04 & 0.29 & 7.01 & 0.31 & 3.53 \\
\hline 12 & NRCGCS-85 & DG & 5.82 & 4.05 & 4.43 & 0.3 & 4.94 & 1.02 & 2.45 \\
\hline 13 & NRCGCS-86 & DG & 8.35 & 6.58 & 4.68 & 0.29 & 5.12 & 1.05 & 2.52 \\
\hline 14 & NRCGCS-102 & DG & 4.81 & 5.19 & 3.16 & 0.28 & 4.66 & 0.39 & 3.41 \\
\hline 15 & NRCGCS-103 & DG & 5.06 & 5.44 & 4.05 & 0.29 & 5.02 & 0.32 & 3.44 \\
\hline 16 & NRCGCS-153 & LG & 6.46 & 6.71 & 3.16 & 0.28 & 4.75 & 0.46 & 3.27 \\
\hline 17 & NRCGCS-159 & DG & 8.10 & 6.46 & 4.43 & 0.27 & 6.51 & 0.72 & 3.41 \\
\hline 18 & NRCGCS-161 & LG & 6.33 & 4.81 & 4.18 & 0.24 & 4.59 & 0.47 & 4.11 \\
\hline 19 & NRCGCS-177 & $\mathrm{DG}$ & 4.81 & 6.33 & 4.05 & 0.29 & 6.05 & 0.33 & 3.62 \\
\hline 20 & NRCGCS-246 & LG & 5.57 & 4.68 & 3.29 & 0.29 & 4.28 & 0.87 & 3.06 \\
\hline 21 & NRCGCS-262 & DG & 6.08 & 6.46 & 4.18 & 0.24 & 6.12 & 0.69 & 3.04 \\
\hline 22 & NRCGCS-267 & DG & 6.20 & 3.80 & 3.42 & 0.25 & 4.23 & 1.01 & 3.05 \\
\hline 23 & NRCGCS-269 & LG & 3.54 & 5.57 & 3.92 & 0.25 & 6.47 & 0.97 & 3.48 \\
\hline 24 & NRCGCS-271 & DG & 5.32 & 4.56 & 3.42 & 0.28 & 5.29 & 0.9 & 3.14 \\
\hline 25 & NRCGCS-275 & DG & 5.57 & 4.94 & 2.53 & 0.3 & 5.06 & 0.89 & 2.59 \\
\hline 26 & NRCGCS-282 & DG & 5.19 & 4.05 & 3.80 & 0.3 & 4.37 & 0.67 & 3.38 \\
\hline 27 & NRCGCS-285 & DG & 6.33 & 3.42 & 3.04 & 0.27 & 4.36 & 0.48 & 2.44 \\
\hline 28 & NRCGCS-286 & DG & 5.82 & 4.56 & 3.29 & 0.3 & 4.45 & 0.77 & 3.25 \\
\hline 29 & NRCGCS-300 & DG & 5.44 & 5.82 & 3.42 & 0.27 & 5.67 & 0.61 & 3.46 \\
\hline 30 & NRCGCS-301 & DG & 7.72 & 6.58 & 4.68 & 0.25 & 5.14 & 0.78 & 3.21 \\
\hline 31 & NRCGCS-319 & DG & 5.44 & 4.56 & 3.16 & 0.29 & 5.33 & 0.96 & 2.43 \\
\hline 32 & NRCGCS-327 & LG & 5.06 & 3.54 & 3.54 & 0.28 & 3.78 & 0.52 & 3.31 \\
\hline 33 & NRCGCS-417 & DG & 5.57 & 4.30 & 2.91 & 0.26 & 5.04 & 0.68 & 4.24 \\
\hline 34 & NRCGCS-421 & DG & 5.70 & 4.68 & 3.54 & 0.28 & 4.21 & 0.36 & 4.54 \\
\hline 35 & KRG - 1 & LG & 2.99 & 2.87 & 2.70 & 0.41 & 6.3 & 0.35 & 5.45 \\
\hline \multirow[t]{4}{*}{36} & TMV2 & LG & 4.12 & 4.00 & 3.85 & 0.35 & 8.05 & 0.22 & 5.21 \\
\hline & S. Em & & 0.27 & 0.22 & 0.17 & 0.01 & 0.22 & 0.07 & 0.03 \\
\hline & CD at $5 \%$ & & 0.75 & 0.61 & 0.48 & 0.02 & 0.63 & 0.19 & 0.10 \\
\hline & CV\% & & 10.62 & 9.92 & 11.04 & 4.65 & 7.11 & 18.73 & 1.65 \\
\hline
\end{tabular}

LC- Leaf colour, LT-Leaf trichomes, PT-Petiole trichomes, ST-Stem trichomes, LTHs-Leaf thickness, TSS- Total soluble sugar, FAA- Free amino acid 
Table.5 Correlation of morphological and biochemical parametersof 34 interspecific prebreeding lines of peanut with PBND incidence

\begin{tabular}{|c|c|c|c|c|c|c|c|}
\hline $\begin{array}{c}\text { Morphological } \\
\text { and } \\
\text { biochemical } \\
\text { parameters }\end{array}$ & $\begin{array}{c}\text { Leaf } \\
\text { trichomes }\end{array}$ & $\begin{array}{c}\text { Petiole } \\
\text { trichomes }\end{array}$ & $\begin{array}{c}\text { Stem } \\
\text { trichomes }\end{array}$ & $\begin{array}{c}\text { Leaf } \\
\text { thickness }\end{array}$ & $\begin{array}{c}\text { Total } \\
\text { soluble } \\
\text { sugar }\end{array}$ & Phenol & $\begin{array}{c}\text { Free } \\
\text { amino } \\
\text { acid }\end{array}$ \\
\hline $\begin{array}{c}\text { PBND } \\
\text { incidence ('r' } \\
\text { value) }\end{array}$ & -0.455 & -0.318 & -0.078 & 0.649 & 0.524 & -0.472 & 0.683 \\
\hline
\end{tabular}

The pedigree of peanut interspecific prebreeding lines did not show any clear cut association or relation with PBND resistance in our study although majority resistant and moderately resistant lines belongs to virginia group. Screening underfield conditions at hot spot location has been successfully used earlier for selection of peanut lines resistant to PBND (Pensuk et al., 2002a, 2002b, 2004; Sunkad et al., 2012; Bera et al., 2014).

Field screening of peanut lines for resistance to PBND under high disease pressure could help in screening large breeding population/ RILs/germplasm and to short list number of lines for further confirmation under artificial conditions. In our studies we selected 16 lines which were resistant over four seasons under high disease pressure at hot spot location. These resistant lines certainly could be fresh donors for resistance to PBND in peanut.

\section{Morphological observations}

Plants respond to herbivory not only through biochemical mechanisms, but also through the induction of morphological features such as trichome density in subsequent plant growth phases (Traw and Dawson, 2002).The genotype with small, green and hairy leaves was less infested and damaged by thrips (Rohilla et al.,1999). In our study the maximum number of leaf trichomes was observed inNRCGCS-86( $\left.8.35 / \mathrm{mm}^{2}\right)$, whereas it was lower in KRG-1 $\left(2.99 / \mathrm{mm}^{2}\right)$ with mean number of $5.63 / \mathrm{mm}^{2}$. The number of petioles trichomes ranged from $2.87 / \mathrm{mm}^{2}$ (KRG-1) to $6.84 / \mathrm{mm}^{2}$ (NRCGCS-79) with a mean $4.92 / \mathrm{mm}^{2}$. The number of stem trichomes ranged from $2.70 / \mathrm{mm}^{2}$ (KRG-1) to $4.68 / \mathrm{mm} 2$ (NRCGCS-86; NRCGCS-301) with a mean of $3.50 / \mathrm{mm}^{2}$ (Table 4). The simple correlation studies confirmed that there is a significant negative relationship of leaf $(r=-0.455)$, petioles $(r=-0.318)$ and stem $(r=-0.078)$ trichomes with PBND incidence (Table 5). Earlier, Dwivedi et al., (1993) and Rao et al., (2015) observed more number of trichomes present in resistant peanut genotypes. Dwivedi et al.,(1986) reported that the presence of long trichomes on the midrib, margin and petiole of leaves contribute to jassid resistance in peanut. The maximum leaf thickness was recorded in TMV2 $(0.41 \mathrm{~mm})$, whereas it was lowest in NRCGCS-79 $(0.22 \mathrm{~mm})$ with general mean of leaf thickness being $0.28 \mathrm{~mm}$ (Table 4). The simple correlation studies confirmed that there is a significant positive relationship of leaf thickness with PBND incidence $(r=0.649)$. Naik and Somasekhar, (2015) also reported that resistant lines had comparatively less leaf thickness, while highly susceptible entries recorded more leaf thickness in peanut. In our study, 26 lines had dark green leaf color (76.47\%) and 8 lines had light green colour (23.53\%) (Table 4). Earlier, Amin, (1985) found that resistance of PBND was associated with dark green leaf colour in peanut. Dwivedi et al., (1993) reported close 
association between resistance to thrips and dark green leaf colour, leaf wax and hairy (Trichomes) characters in peanut cultivar ICGV-86031. Reddy et al., (1996) and Rohilla, (1999) also reported that the thrips resistant cultivars of peanut had the small elliptical and green leaves.

\section{Biochemical observations}

Total sugar soluble content of peanut interspecific pre-breeding lines varied from $3.78 \mathrm{mg}$ (NRCGCS-327) to $8.05 \mathrm{mg}$ (TMV2) per gram of leaf sample (Table 4). The simple correlation studies confirmed that there is a significant positive relationship of TSS with PBND incidence $(r=0.524)$. The insect susceptible plant parts had higher concentration of sugars (Lapidus et al., 1963; Knapp et al., 1965 and Kalode and Pant, 1967). Somasekhar et al., (2003) found that the resistant lines showed lower amount of soluble sugars than the susceptible lines of peanut. Mahatma et al., (2009) reported that the total soluble sugar was 2-3 fold higher in highly susceptible genotypes (J-2296 and $7042 \mathrm{~S}$ ) compared to resistant genotypes in pearl millet. The data recorded on phenol content varied from $0.22 \mathrm{mg}$ (TMV2) to 1.05 mg (NRCGCS-86) per gram of leaf sample (Table 4).

The resistant lines had higher amount of phenols compared to susceptible lines. The simple correlation studies confirmed that there is a significant negative relationship with phenol content and PBND incidence ( $\mathrm{r}=$ -0.472) (Table 5). In peanut too, phenols play a major role in imparting resistance against Empoascakerri (Anon. 1984). Rohini et al., (2011) reported that the presence of high quantity of biochemical components like tannins, phenols conferred resistance against thrips. Somasekhar et al., (2003) reported that the thrips resistant varieties of peanut had higher quantity of phenols. However, this study suggests that phenols have the major role in imparting resistance against PBND in peanut. The free amino acid content varied from $2.43 \mathrm{mg}$ (NRCGCS-319) to $5.45 \mathrm{mg}$ (KRG-1) per gram of leaf sample (Table 4). The highest amount of free amino acids was recorded in susceptible lines compared to resistant lines. The simple correlation coefficient between amino acids and PBND incidence was positively significant $(\mathrm{r}=$ 0.683).Swami et al., (2015) reported that free amino acid content is higher in infected/susceptible plants compare to noninfected/resistant plants in pigeon pea.

In conclusion, the present studies showed, morphological and biochemical factors play a major role in the resistance mechanism against PBND in peanut. The results indicated a lot of variation in the morphological and various biochemical analysis among interspecific pre-breeding lines.

The total soluble sugars, free amino acids and leaf thickness have positive significant association with PBND incidence. While, phenol content, leaf trichomes, petioles trichomes, stem trichomes have significant negative association with PBND incidence. The studies revealed that the interspecific prebreeding lines viz. NRCGCS-79, NRCGCS86, NRCGCS-159, NRCGCS-301 have shown resistant to PBND and also recorded higher amount of phenol, more number of plant trichomes (leaf, stem and petioles) and dark green color compare to susceptible checks. All four interspecific pre-breeding lines belong to virginia bunch habit group. Development of interspecific pre-breeding lines with resistance to PBND will help breeding PBND resistant peanut variety. Identified PBND resistant interspecific prebreeding lines would widen the genetic base of cultivated peanut and would be fresh sources for resistance to PBND in future peanut breeding program. 


\section{References}

Amin, P.W. 1985. Apparent resistance of groundnut cultivar Robot 33-1 to bud necrosis disease. Plant dis. 69:718-719.

Anonymous. 1984.Annual Progress Report, groundnut, XXVI ,All India Coordinated Research Project (AICRP) on Groundnut, Rajendra Agriculture University, Patna, Bihar. Pp. 224.

Basu, M.S.1995. Peanut bud necrosis disease: activities in the Indian national program. In: Recent studies on peanut bud necrosis disease. Proceedings of a meeting of ICRISAT Asia center, India. Pp. 61-63.

Bera, S.K. and Sunkad, G. 2016. Pre-breeding lines of groundnut resistant to Peanut Bud Necrosis Disease. ICAR-Directorate of Groundnut Research, PB \# 5, Ivnagar Road, Junagadh - 362001, Gujarat, India. Technical Bulletin No. 2, Pp. 20.

Bera, S.K., Kamdar, J.H., Maurya, A.K. and Dash, P. 2014. Molecular diversity and association of simple sequence repeat markers with bud necrosis disease in interspecific breeding lines and cultivars of peanut (Arachis hypogaea L.). Aust. J. Crop Sci. 8(5): 771-780

Bera, S.K., Vinod K., Sunkad, G., Rathnakumar, A.L. and Radhakrishnan, T. 2010a. NRCGCS-86 (INGR 10031) Multiple Disease Resistant Spanish Bunch Groundnut Genotype (resistant to stem rot, late leaf spot, early leaf spot, rust, alternaria leaf blight and PBND). Indian J. Pl. Genet.Resources.24:112.

Bera, S.K., Vinod K.,Sunkad, G., Rathnakumar, A.L. and Radhakrishnan, T. $2010 \mathrm{~b}$. NRCGCS-85 (INGR 10030) - Multiple Disease Resistant Spanish Bunch Peanut Genotype (resistant to PBND, stem rot, late leaf spot, early leaf spot, alternaria leaf blight and tolerant to rust). Indian J. Pl. Genet. Resources. 24: 111

Bertioli, D.J., Cannon, S.B., Froenicke, L., Huang, G., Farmer, A.D., Cannon, E.K., Liu, X., Gao, D., Clevenger, J., Dash, S.,
Ren, L., Moretzsohn, M.C., Shirasawa, K., et al. 2016. The genome sequences of Arachis duranensis and Arachis ipaensis, the diploid ancestors of cultivated peanut. Nat. Genet. 48:438-446

Buiel, A.A.M. 1993. Resistance in peanut to peanut bud necrosis virus In: Durability of disease resistance. Kluwer Academic Publishers, the Netherlands. Pp. 207-210.

Darvhankar, M.S. 2017. Gene action and identification of quantitative trait loci (qtls) for drought related traits in groundnut (Arachis hypogaea L.). Phd. Thesis, Junagadh Agricultural University, Junagadh, Gujarat, India.

Darvhankar, M.S., Kamdar, J.H., Kasundra, S.V., Jasani, M.D., Kulkarni, G.U. and Bera, S.K. 2016. Assessment of yield and yield related traits in recombinant inbred lines of groundnut (Arachishypogaea L.) using principal component and cluster analysis. The Bioscan. 11(3): 2025-2030.

Dwivedi, S.L., Amin, P.W., Rasheedunisa, Nigam, S.N., Nagabhushanam, G.V.S., Rao, V.R. and Gibbons, R.W. 1986. Genetic analysis of trichome characters associated with resistance to jassid (EmpoascakerriPruthi) in peanut. Peanut Sci. 13:15-18

Dwivedi, S.L., Reddy, D.V.R., Nigam, S.N., Rao, G.V.R., Wightman, J.A., Amin, P.W., Nagabhushanam, G.V.S., Reddy, A.G.S., Scholberg, E. and Ramraj, V.M.1993. Registration of ICGV 86031.Peanut germplasm. Crop Sci.36:220.

FAOSTAT. 2015. Available: http://faostat.fao.org.

Franscistt, W., David, F.B. and Robert, M.D. 1971. Experiment in Plant Physiology, Van, Nostrand Reinhold Camp, New York. Pp. 16.

Gopal, K., Upadhyaya, H.D.1988.Effect of bud necrosis disease on yield of groundnut (Arachis hypogaeaL.).Indian Phytopathol. 32: 122-123.

Hong-Qin, S. and Jian-Ping, L.2010.Comparison of drought resistance of pepper with 
different hairiness character under drought stress. J. Nucl. Agri. Sci. 24: 835839.

Jasani, M.D. and Kamdar, J.H. 2015.Peanut Bud Necrosis Disease. Indian Farmer. 2: 242-244.

John Peter, A., Shanower, T.G. and Romeis, J. 1995. The role of plant trichomes in insect resistance: A Selective Review. Crop Protection Division, ICRISAT Asia Center, Patancheru, A.P. 502 324, India.

Kalode, M. B., and Pant, N. C. 1967. Studies on the amino acids, nitrogen, and moisture content of maize and sorghum varieties and their relation to Chilo zonellus (Swin.) resistance. Indian J. Ent. 29(2): 139-144.

Kamdar, J.H., Goswami, B.R. and Bera, S.K. 2014.Genetic molecular diversity in interspecific peanut lines differing in temporal resistance to peanut bud necrosis. Afr. J. Biotech. 13(3): 385-393.

Kandakoor, S.B., Khan, H.K., Chakravarthy, A.K., Ashok Kumar, C.T. and Venkataravana, P. 2014. Biochemical constituents influencing thrips resistance in groundnut germplasm. J. Envir. Bio. 35: 675-681.

Knapp, J. L., Hedin, P. A. and Douglas, W. A. 1965.Amino acids and reducing sugars in silks of corn resistant or susceptible to corn earworm. Ann. Ent. Soc. Amer. 58(3): 401-402.

Krishnaiah, M.K., Manjula. andVasanthi, R.P. 2012. Screening of groundnut genotypes against thrips. Ann. Plant Protec. Sci. 20: 480-481.

Lapidus, J.B., Cleary, R.W., Davidson, R.H., Fish, F.W., and Augustine, M.G. 1963. Plant Susceptibility to Insects, Chemical Factors Influencing Host Selection by the Mexican Bean Beetle Epilachna varivestis Muls. J. Agric. Food. Chem. 11: 402-463.

Lee, Y.P. and Takahanshi, J.1966. An improved determination of amino acid with use of ninhydrin. Ann. Biochem. 14: 71.

Linch, R.E., and Stalker, H.T. 1997. Evaluation of Arachis hypogaea L. $\times$ A. Cardenarsii
Interspecific lines for resistance to insect pests. Peanut Sci. 24: 89-86

Mahatma, M.K., Bhatnagar, R., Dhandhukia, P. and Thakkar, V.R. 2009.Variation in metabolites constituent in leaves of downy mildew resistant and susceptible genotypes of pearl millet.Physiol. Mol. Biol. Plants. 15(3): 249-255

Malik, C.P. and Singh, M.B. 1980. In: Plant Enzymology and Histo-Enzymology, Kalyani Publications, New Delhi. Pp. 286

Naik, O. S. 2005. Studies on sucking insect pests of groundnut. M.Sc.(Agri.) Thesis, University Agricultural Sciences, Dharwad, Karnataka, India.

Naik, S. and Somashekhar. 2015. Phenotypic and biochemical mechanism of resistance in groundnut genotype and varieties against leafhopper and thrips. Eco. Env. Cons. 21(1): 535-543.

Pensuk, V., Daengpluang, N., Wongkaew, S., Jogloy, S. and Patanothai, A. 2002a.Evaluation of screening procedures to identify peanut resistance to peanut bud necrosis virus (PBNV). Peanut Sci. 29(1): 47-51.

Pensuk, V., Jogloy, S., Wongkaew, S. and Patanothai, A. 2004. Generation means analysis of resistance to peanut bud necrosis caused by peanut bud necrosis tospovirus in peanut. Plant Breed. 123: 90-92.

Pensuk, V., Wongkaew, S., Jogloy, S. and Patanothaoi, A. 2002b. Combining ability for resistance in peanut (Arachis hypogaea L.) to Peanut bud necrosis tospovirus (PBNV). Ann. Applied. Biol. 141: 143-146.

Rao, A.R., Krishna, T.M., John, K., Sudhakar, P., Devaki, K. and Rajendra Prasad, P.A. 2015. Influence of morphological traits on resistance of groundnut genotypes for thrips. Afr. J. Biotech. 10(4): 250-263

Rathnakumar, A.L., Singh, R., Parmar, D.L. and Misra, J.B. 2013. Groundnut: a crop profile and compendium of notified varieties of India, Directorate of Groundnut Research, P.B.No.5, Junagadh-362 001, Gujarat, India. Pp.118 
Reddy, D.V.R. 1988.Virus diseases. In: P.S. Reddy (Ed.) Groundnut. Indian Council of Agricultural Research, New Delhi, India. 583 Pp. 508-525

Reddy, D.V.R., Buiel, A.A.M., Satyanarayana, T., Dwivedi, S.L., Reddy, A.S., Ratna, A.S., Vijaya Lakshmi, K., Rao, G.V.R., Naidu, R.A. and Wightman, J.A. 1995. Peanut bud necrosis disease: an overview. In: Recent studies on peanut bud necrosis disease. Proceedings of a meeting of ICRISAT Asia center, India, Pp. 3-7.

Reddy, L.J., Nigam, S.N., Moss, J.P., Singh, A.K., Subrahmanyam, P., McDonald, D. and Reddy, A.G.S. 1996. Registration of ICGV 86699 peanut germ line with multiple with multiple disease and insect resistance. Crop Science. 36(3): 821

Rohilla, H.R., Singh, H., Batra, G.R. and Singh, H. 1999. Field evaluation of groundnut genotypes for resistance to thrips.Ann. Bio. Ludhiana. 15(2): 219-221.

Rohini, A., Prasad, N.V.V.S.D., Chalam, M.S.V. and Veeraiah, K. 2011. Identification of suitable resistant cotton genotypes against sucking pests. J. Ent. Res. 35:197-202.

Singh, A.B. and Srivastava, S.K. 1995.Status and control strategy of peanut bud necrosis disease in Uttar Pradesh. In: Recent studies on peanut bud necrosis disease. Proceeding of a meeting at
ICRISAT Asia center, India, Pp. 65-68.

Somashekhar, N.S., Onkara and Patil, B.V. 2003. Mechanism of resistance in ground nut cultivars against thrips. Proceedings of National Symposium on Frontier Areas of Entomological Research. November 57, Pp. 401-402

Sunkad, G., Basavaraj, N. and Srinivasaraghavan, A. 2012.Survey for the incidence and sources of field resistance against peanut bud necrosis disease of groundnut in north eastern Karnataka. The Bioscan. 7: 387-390.

Swami, R.M., Mahatma, M.K., Parekh, M.J., Kalariya, K.A. and Mahatma, L. 2015. Alteration of Metabolites and Polyphenol Oxidase Activity in Wilt Resistant and Susceptible Pigeonpea Genotypes. Indian J. Agri. Biochem. 28(1): 18-23

Traw, B.M. and Dawson, T.E. 2002. Differential induction of trichomes by three herbivores of black mustard. Oecologia. 131:526-532.

Vijayalakshmi, K., Wightman, J.A., Reddy, D.V.R., Ranga Rao, G.V., Buiel, A.A.M., Reddy, D.D.R. 1995. Thrips: Biology and Management, NATO ASI series, Life sciences 276.Transmission of peanut bud necrosis virus by Thrips palmiKarny in India. New York and London: Plenuno Press. 179-184.

\section{How to cite this article:}

Jasani, M.D., A.K. Maurya, P. Dash, J.H. Kamdar, G. Sunkad, M.K. Mahatma and Bera, S.K. 2018. Identification of Peanut Interspecific Pre-breeding Lines resistance to Peanut Bud Necrosis Disease (PBND): Field Screening, Morphological and Biochemical Parameters. Int.J.Curr.Microbiol.App.Sci. 7(02): 1928-1939. doi: https://doi.org/10.20546/ijcmas.2018.702.232 